\author{
Asian Journal of \\ Medical and Biological Research \\ ISSN 2411-4472 (Print) 2412-5571 (Online) \\ www.ebupress.com/journal/ajmbr
}

\title{
Article \\ Workplace environment and performance of nurses in a tertiary level hospital
}

\author{
Nasima Akhter ${ }^{1}$, Ashees Kumar Saha ${ }^{2}$, Mst. Jannat Ara Ahmed ${ }^{3}$, Muhshina Begum ${ }^{4}$, Priti Kana Borua ${ }^{5}$, \\ Ringku Das ${ }^{6}$ and Md. Mahmudul Haque ${ }^{7}$ \\ ${ }^{1}$ Bandarban Nursing College, Bandarban, Bangladesh \\ ${ }^{2}$ Nursing Officer, Upazila Health Complex, Bagha, Rajshahi, Bangladesh \\ ${ }^{3} 250$ Bedded General Hospital, Jashore, Bangladesh \\ ${ }^{4}$ Mugda Medical College Hospital, Mugda, Dhaka, Bangladesh \\ ${ }^{5}$ Fouzderhat Nursing College, Chattogram, Bangladesh \\ ${ }^{6} 250$ Bedded Chattogram General Hospital, Chattogram, Bangladesh \\ ${ }^{7}$ NIPSOM, Mohakhali, Dhaka, Bangladesh
}

*Corresponding author: Nasima Akhter, Bandarban Nursing College, Bandarban, Bangladesh. Phone: +8801557070564, Email: nasimasunthu@gmail.com

Received: 14 November 2020/Accepted: 13 December 2020/ Published: 31 December 2020

\begin{abstract}
Workplace environment is an integral part of a hospital. The workplace environment influences on nurses' performance both positively and negatively. A cross-sectional study was conducted in Chittagong Medical College Hospital, Chittagong from $1^{\text {st }}$ January to $31^{\text {st }}$ December 2017 with the aim to assess the workplace environment and performance of nurses. Total respondents in this study were 210 nurses. Samples were selected by purposive sampling technique. After taking written consent from the respondents, data collection was done by face to face interview using a semi-structured questionnaire with the help of Copenhagen Psychosocial Questionnaire II and Performance Evaluation Rating Scale. Data were analyzed using SPSS. The study findings revealed that $43.3 \%$ had good, $51.4 \%$ average and $5.2 \%$ poor state of physical environment and $10.0 \%$ had good, $88.1 \%$ average and $1.9 \%$ poor state of psychosocial environment. Therefore $70.5 \%$ respondents' performance needed some improvement. The results revealed that there was a significant relationship between educational qualification and workplace performance of nurses ( $p<0.001$; pulled from $\chi^{2}$ text) and psychosocial environment and workplace performance of nurses $\left(\mathrm{p}<0.015\right.$; pulled from $\chi^{2}$ text). So, a conducive workplace environment is very crucial in every hospital to improve nurses' performance and provide quality care.
\end{abstract}

Keyword: Workplace environment, physical environment, psychosocial environment, performance, workplace, nurse.

\section{Introduction}

Nurses are one of the most diverse and largest workforces in the health care system. The word "nurse" originated from Latin word "Nutricius" which means someone who nourishes, fosters and protects. The role of nurses in the health care system is expanding and changing. Their role is not just limited to institutional care but also involves delivery of services at various levels of the health care system. The nurses are one of the strongest pillars of the health care delivery system in providing safe, affordable and quality services to the people. Mortality, morbidity and disability reduction, health promotion through healthy lifestyles are positive health outcomes in which nurses have a pivotal role (WHO, 2013). They play a major role in maintaining health status and also in achieving the health related targets of the country. Health promotion, prevention, institutional care and rehabilitation services are essential contribution of nurses to the health care system. Despite their vital role within the health care system, nurses remain as the invisible workforce of health care delivery system. 
Environment literally means surroundings and all those things that impact human being during the life time is collectively recognized as environment. A working environment is the environment where nurses' work together for achieving hospital objectives. It means systems, processes, structures and tools and all those things which interact with nurses' and affect in positive or negative ways on nurses' performance. It can also be defined as the location where a task is completed. When studying place of employment, the work environment involves the physical geographical location as well as the immediate surroundings of the workplace such as a construction site or office building. It typically involves other factors relating to the place of employment such as the quality of the air, noise level and benefits of employment such as cafeteria (Awan and Tahir, 2015). Lighting and other factors like ergomic furniture has also been found to have positive influence on employees health and consequently on productivity. Ambient features in office environments, such as lighting, temperature, existence of windows, free air movement etc, suggest that these elements of the physical environment influence employee's attitudes, behaviors, satisfaction, performance and productivity (Pepple et al., 2017). According to Källestål (2004) this environment involves the physical location as well as the immediate surroundings, behavioral procedures, policies, rules, culture, resources, working relationships, work location, all of which influence the ways nurses perform their work. The psychosocial work environment has been defined as psychological work demands, influence and control over work, good contact with and support from supervisor and fellow workers, stimulation from work and opportunities for development. The quality of the workplace environment impacts on nurses' performance and subsequently influences the hospital competiveness. An effective workplace environment management entails making work environment attractive, comfortable, satisfactory and motivating to employees so as to give employees a sense of pride and purpose in what they do (Samson et al., 2015). Factors of workplace environment have a great impact on nurses' performance. These factors enjoys a key role in the performance of nurses either high or low performance outcome. The performance of the nurses is related to the commitment of the nurses towards job. Nurses when feel satisfied they work hard and perform better. In health system, high level nurses performance leads to patient safety, security, proper treatment, attachment or affiliation with hospitals and peers. Whereas poor or below par performance can result in Poor process, improper treatment, lack of quality, absenteeism and can disturb entire working system (Khoso et al., 2016).

Nurses' job satisfaction has emerged as burning issue for the health care sectors, particularly in the government hospitals. Nurses are working in health care organizations that are wrestling with staff shortage; increasing patient loads, shrinking reimbursement and growing regulating pressure (Bhaga, 2011). They are carrying out their responsibilities in a very poor working environment and with an enormous discrepancy between the supplies and demands of workforce and resources. They have faced a variety of challenges in several ways: such as poor health care delivery system, under staffing, poor distribution of responsibility and high workload, low salary structure and less opportunity for personal and professional developmental. In addition, there is a lack of effective nursing leadership. Therefore, many professional demands are often unmet, because nurses have less opportunity to speak out in the policy level (Latif et al., 2014). Job satisfaction among nurses is a major concern in Bangladesh; no research evidence has existed about the factors associated with nurses' job satisfaction in the country. In this regards, some surveys reported that job satisfaction among nurses in Bangladesh was near to the ground (Hossain et al., 2016).

A healthy workplace environment makes good business sense and is characterized by respect that supports employee engagement and creates a high performance culture that encourages innovation and creativity. Organizations deemed as a positive place to work will more likely have a competitive edge since they are in a better position to attract and retain highly skilled employees'. This is a significant consideration in the current tight labor market. A positive workplace environment is likely to result in less employee turnover, fewer cases of fraud, better safety practices, easier to attract and retain qualified employees and improved employees' wellbeing (Samson et al., 2015).

According to Naharuddin and Sadegi (2013) when the nurses' are physically and emotionally have the desire to work, then their performance outcomes shall be increased. Moreover, they also stated that by having a proper workplace environment, it helps in reducing the number of absenteeism and thus can increase the nurses' performance which will leads to the increasing number of productivity at the workplace.

In Bangladesh, particularly Chittagong, work place environments and the problems associated with it are always neglected. Work and workplace tools have become important part of the today's environment. Harmful, insecure, and risky environment can create tremendous problems in working environment. Similarly, psychosocial workplace environment (supervisor support, trust, workload, recognition, rewards) has also become one of the critical factors in the performance of nurses in hospital. Lack of proper support can de motivate and create serious dissatisfaction within the employees. In this labor intensive sector losing the key 
staff can become great loss to the organization. Hospitals therefore have to create a workplace environment where their employees take pleasure in their work, believe their output is appreciated and rewarded appropriately enabling them to reach their potential. Whereas, previous studies have shown that proper support has brought remarkable positive results. Furthermore, physical environment is considered as one of the important factor to affect performance. Therefore it is important to investigate the factors that affect the performance of nurses in hospital. The research study was important because no study has been conducted previously in Chittagong, regarding the factors of workplace environment that affect the performance of nurses. For the purpose of research whether to assess the workplace environment and performance of nurses in a tertiary level hospital.

\section{Methods and Materials}

\subsection{Ethical considerations}

Ethical permission from NIPSOM ethical review committee and Director of Chittagong Medical College Hospital was taken before data collection. Neither any intervention nor any invasive procedure was done. Written informed consent was provided before data collection. Privacy and confidentiality of the data was maintained following standard guideline. The information obtained was published for research and technical purpose without mentioning the name and address the respondents.

\subsection{Study design}

A cross-sectional study was conducted.

\subsection{Study population}

Nurses were working in Chittagong Medical College Hospital, Chittagong.

\subsection{Study period and others}

The study was from $1^{\text {st }}$ January to $31^{\text {st }}$ December, 2017.

\subsubsection{Study place}

The study was conducted at Chittagong Medical College Hospital, Chittagong, which is a government tertiary level hospital.

\subsubsection{Sampling technique}

A Purposive sampling technique was followed to select the sample. Sample size were 210.

\subsubsection{Inclusion criteria}

The inclusion criteria were, Nurses who were worked in the hospital for more than six month, nurses who were presented in the hospital during data collection time and respondents who agreed to participate in the study.

\subsubsection{Exclusion criteria}

Exclusion criteria were, respondents who were physically sick and nursing management personnel.

\subsubsection{Tools of the study}

Semi-structured questionnaire prepared by using Copenhagen Psychosocial Questionnaire (COPSOQ) and Performance Evaluation Rating Scale. Physical environment related questions consist of 17 items that reflected the physical workplace environment situation of nurses in Chittagong Medical College Hospital. Five point likert score was used with rankings of 1 Not at all, 2 slightly, 3 moderate, 4 considerably, 5 extensively where higher score indicated higher exposure. A sum score was calculated from the 17 items. Range of possible score was 17 to 85 . For easy measurements 17 items were categorized under 3 broad headings like, 17-39 score considered as good, 40-62 considered as Average and 63- 85 indicate poor from the total score of physical environment. Performance evaluation rating scale was a performance evaluation direction used by the human resources office of Lamer Institute of Technology to measure the performance of their employees. The scale included 14 questions defining performance. These questions are also prepared based on the 5-point Likert Scale with ranking of 1 means major improvement needed, 2 some improvement needed, 3 meets expectations, 4 often exceeds expectations, 5 consistently exceeds expectations. Here, major improvement needed response represented the most negative and unfavorable rating while consistently exceeds expectations response represented the most positive one. Therefore, the ratings close to 5 means performance is increased and 
consistently exceeds expectations and those close to 1 means performance is reduced and major improvement needed in their performance. A sum score was calculated from the 14 items. Range of possible score was 14 to 70. 14-25 indicate Major improvement needed, 26-36 some improvement needed, 37-47 Meet expectations, 4858 often exceeds expectation and 59-70 consistently exceeds expectation. Data from the respondents were collected through face-to-face interview by using the pre -designed questionnaire. Data analysis was done by the use of computer with the help of software statistical package for social science (SPSS) version 20.

\section{Results and Discussion}

This cross sectional study was conducted in a tertiary level hospital named Chittagong Medical College Hospital. The study was aimed to find out the existing workplace environment and performance level of Nurses and association in between them. The demographic characteristics of the respondents are shown in Table 1.

Table 1. Socio-demographic characteristics of the respondents $(n=210)$.

\begin{tabular}{|c|c|c|c|}
\hline Gender & Frequency & Percentage & Statistics \\
\hline Female & 192 & $91.4 \%)$ & \\
\hline Male & 18 & $8.6 \%$ & \\
\hline \multicolumn{4}{|l|}{ Age (years) } \\
\hline $20-29$ & 16 & 7.6 & \multirow{4}{*}{ Std. Deviation $= \pm 6.22$} \\
\hline $30-39$ & 96 & 45.7 & \\
\hline $40-49$ & 90 & 42.9 & \\
\hline $50-59$ & 8 & 3.8 & \\
\hline \multicolumn{4}{|l|}{ Educational qualification } \\
\hline Diploma in Nursing & 118 & $56.2 \%$ & \\
\hline Nursing graduation & 74 & $35.2 \%$ & \\
\hline Post-graduate & 18 & $8.6 \%$ & \\
\hline \multicolumn{4}{|l|}{ Monthly income(Taka) } \\
\hline $25000-29000$ & 17 & 8.1 & \multirow{6}{*}{ Std. Deviation $= \pm 5238.056$} \\
\hline 30000- 34000 & 75 & 35.7 & \\
\hline $35000-39000$ & 87 & 41.4 & \\
\hline $40000-44000$ & 12 & 5.7 & \\
\hline $45000-49000$ & 8 & 3.8 & \\
\hline $50000-59000$ & 11 & 5.2 & \\
\hline \multicolumn{4}{|l|}{ Type of family } \\
\hline Nuclear family & 176 & $83.3 \%$ & \\
\hline Extended family & 34 & 16.7 & \\
\hline \multicolumn{4}{|l|}{ Place of working ward } \\
\hline Medicine ward & 35 & $14.3 \%$ & \\
\hline Surgery ward & 35 & $14.3 \%$ & \\
\hline Gynaecology and obstetrics & 26 & $12.4 \%$ & \\
\hline Pediatrics & 20 & $9.5 \%$ & \\
\hline Cardiology & 19 & $9.0 \%$ & \\
\hline Orthopedics & 15 & $7.1 \%$ & \\
\hline Nephrology, & 15 & $7.1 \%$ & \\
\hline Oncology & 10 & $4.8 \%$ & \\
\hline Gastroenterology, ENT and emergency ward. & 35 & $14.3 \%$ & \\
\hline \multicolumn{4}{|l|}{ Duration of service (years) } \\
\hline $0-4$ & 51 & 24.3 & \multirow{7}{*}{ Std. Deviation $= \pm 6.320$} \\
\hline $5-9$ & 31 & 14.8 & \\
\hline $10-14$ & 61 & 29.0 & \\
\hline $15-19$ & 44 & 21.0 & \\
\hline $20-24$ & 16 & 7.6 & \\
\hline $25-29$ & 7 & 3.3 & \\
\hline Total & 210 & 100 & \\
\hline
\end{tabular}

Table 1 shows that most of the respondents $192(91.4 \%)$ were female and $18(8.6 \%)$ respondents were male. About half of the respondents $96(45.7 \%)$ were aged between 30 to 39 years, 90 (42.9\%) respondents were aged between 40 to 49 years, $16(7.6 \%)$ were aged between 20 to 29 years and the rest of respondents were belonged to age group 50-59 years. Mean age of the respondents was 38.23 with Std. Deviation \pm 6.221 years. From the 
findings more than half $118(56.2 \%)$ of the respondents had diploma, $74(35.2 \%)$ respondents had graduation and $18(8.6 \%)$ respondents had post-graduate degree of education. Nearly half of the respondents $87(41.4 \%)$ had monthly income between 35000 to 39000 taka, 75 (35.7\%) respondents had monthly income between 30000 to 34000 taka, Mean monthly income of the respondents was 35190.48 with Std. Deviation \pm 5238.056 taka. Out of 210 respondents, $176(83.3 \%)$ respondents were from nuclear family and the rest were from joint and extended family and from them 35 (14.3\%) respondents were working in medicine ward, 35 (14.3\%) respondents were working in surgery ward, $26(12.4 \%)$ respondents were working in gynaecology and obstetrics, $20(9.5 \%)$ respondents were working in pediatrics, $19(9.0 \%)$ respondents were working in cardiology, $15(7.1 \%)$ respondents were working in orthopedics, $15(7.1 \%)$ respondents were working in nephrology, $10(4.8 \%)$ were working in oncology and the rest of respondents were working in gastroenterology, ENT and emergency ward. Most of the respondents 61 (29.0\%) had served within the range of 10 to 14 years with Std. Deviation \pm 6.320 years.

Table 2. Distribution of the respondents regarding physical environment factors affecting their work (n210).

\begin{tabular}{|c|c|c|c|c|c|}
\hline Physical environment & Not at all & Slightly & Moderate & Considerably & Extensively \\
\hline Office building space & - & $58(27.6 \%)$ & $97(46.2 \%)$ & $55(26.2 \%)$ & - \\
\hline Availability of electricity & $143(68.1 \%)$ & $67(31.9 \%)$ & - & - & - \\
\hline Availability of lighting & $22(10.5 \%)$ & $105(50.0 \%)$ & $60(28.6 \%)$ & $23(11.0 \%)$ & - \\
\hline Availability of Water & $109(51.9 \%)$ & $78(37.1 \%)$ & $23(11.0 \%)$ & - & - \\
\hline Old furniture & $25(11.9 \%)$ & $87(41.4 \%)$ & $82(39.0 \%)$ & $16(7.6 \%)$ & - \\
\hline Overcrowding & - & - & $48(22.9 \%)$ & $117(55.7 \%)$ & $45(21.4 \%)$ \\
\hline Noise & - & - & $55(26.2 \%)$ & $112(53.3 \%)$ & $43(20.5 \%)$ \\
\hline $\begin{array}{l}\text { Availability of } \\
\text { ventilation }\end{array}$ & - & $99(47.1 \%)$ & $90(42.9 \%)$ & $21(10.0 \%)$ & - \\
\hline Cleanliness & $35(16.7 \%)$ & $114(54.3 \%)$ & $40(19.0 \%)$ & $21(10.0 \%)$ & - \\
\hline $\begin{array}{l}\text { Availability of } \\
\text { emergency drugs }\end{array}$ & $66(31.4 \%)$ & $87(41.4 \%)$ & $43(20.5 \%)$ & $14(6.7 \%)$ & - \\
\hline $\begin{array}{l}\text { Availability of staff } \\
\text { personnel }\end{array}$ & $33(15.7 \%)$ & $105(50.0 \%)$ & $51(24.3 \%)$ & $21(10.0 \%)$ & - \\
\hline Availability of PPE & $78(37.1 \%)$ & $93(44.3 \%)$ & $25(11.9 \%)$ & $14(6.7 \%)$ & - \\
\hline $\begin{array}{l}\text { Prolonged standing } \\
\text { position }\end{array}$ & - & $57(27.1 \%)$ & $103(49.0 \%)$ & $41(19.5 \%)$ & $9(4.3 \%)$ \\
\hline Uncomfortable posture & - & $20(9.5 \%)$ & $90(42.9 \%)$ & $80(38.1 \%)$ & $20(9.5 \%)$ \\
\hline Changing room & $19(9.0 \%)$ & $74(35.2 \%)$ & $92(43.8 \%)$ & $21(10.0 \%)$ & $4(1.9 \%)$ \\
\hline Prayer room & $55(26.2 \%)$ & $85(40.5 \%)$ & $54(25.7 \%)$ & $16(7.6 \%)$ & - \\
\hline Cafeteria & $194(92.4 \%)$ & $16(7.6 \%)$ & - & - & - \\
\hline
\end{tabular}

It was seen from the Table 2 that, out of 17 items, most of the respondents mentioned that 5 items (office building space, noise, overcrowding, prolonged standing position and uncomfortable posture) influenced their works considerably. Figure 1 mentioned that, state of physical environment had good 91(43.3\%), average $108(51.4 \%)$, and poor $11(5.2 \%)$.

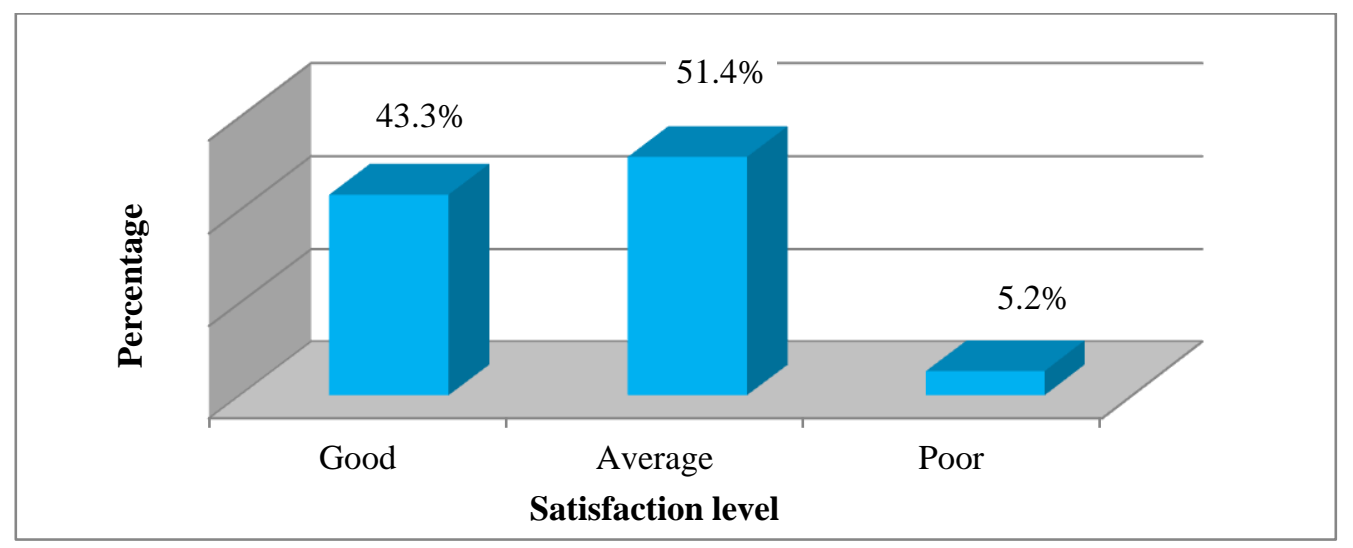

Figure 1. Distribution of the Nurses by state of physical environment $(\mathbf{n}=210)$. 
Asian J. Med. Biol. Res. 2020, 6 (4)

Table 3. Distribution of the respondents regarding situation of psychosocial environment $(n=210)$.

\begin{tabular}{|c|c|c|c|}
\hline Psychosocial environment & Poor & Average & Good \\
\hline Quantitative demands & $79(36.6 \%)$ & $54(25.7 \%)$ & $77(36.7 \%)$ \\
\hline Work pace & $49(23.3 \%)$ & $83(39.5 \%)$ & $78(37.1 \%)$ \\
\hline Emotional demands & $30(14.3 \%)$ & $85(40.5 \%)$ & $95(45.2 \%)$ \\
\hline Influence & $61(29.0 \%)$ & $91(43.3 \%)$ & $58(27.6 \%)$ \\
\hline Degree of freedom at work & $97(46.2 \%)$ & $72(34.3 \%)$ & $41(19.5 \%)$ \\
\hline Role clarity & - & $51(24.3 \%)$ & $159(75.7 \%)$ \\
\hline Quality of leadership & $48(22.9 \%)$ & $95(45.2 \%)$ & $67(31.9 \%)$ \\
\hline Social support from Supervisors & $80(38.1 \%)$ & $91(43.3 \%)$ & $39(18.6 \%)$ \\
\hline Social Community at work & $42(20.0 \%)$ & $78(37.1 \%)$ & $90(42.9 \%)$ \\
\hline Trust regarding management & $50(23.8 \%)$ & $83(39.5 \%)$ & $77(36.7 \%)$ \\
\hline Justice and respect & $43(20.5 \%)$ & $95(45.2 \%)$ & $72(34.3 \%)$ \\
\hline Rewards & $103(49.0 \%)$ & $68(32.4 \%)$ & $39(18.6 \%)$ \\
\hline Job satisfaction & $29(13.8 \%)$ & - & $181(86.2 \%)$ \\
\hline Burnout & $51(24.3 \%)$ & $87(41.4 \%)$ & $72(34.3 \%)$ \\
\hline Stress & $94(44.8 \%)$ & $62(29.5 \%)$ & $54(25.7 \%)$ \\
\hline Self-rated health & - & $24(11.4 \%)$ & $186(88.6 \%)$ \\
\hline Work-family conflict & $56(26.7 \%)$ & $83(39.5 \%)$ & $71(33.8 \%)$ \\
\hline
\end{tabular}

It was seen from the Table 3 that, out of 17 items, respondents mentioned that 4 items (quantitative demands, degree of freedom, rewards and stress) had poor and 8 items (work pace, influence, quality of leadership, social support from supervisors, trust regarding management, justice, work-family conflict and respect and burnout) had average and the rest were 5items (emotional demands, role clarity, social community at work, job satisfaction and self-rated heath) good during to providing their service.

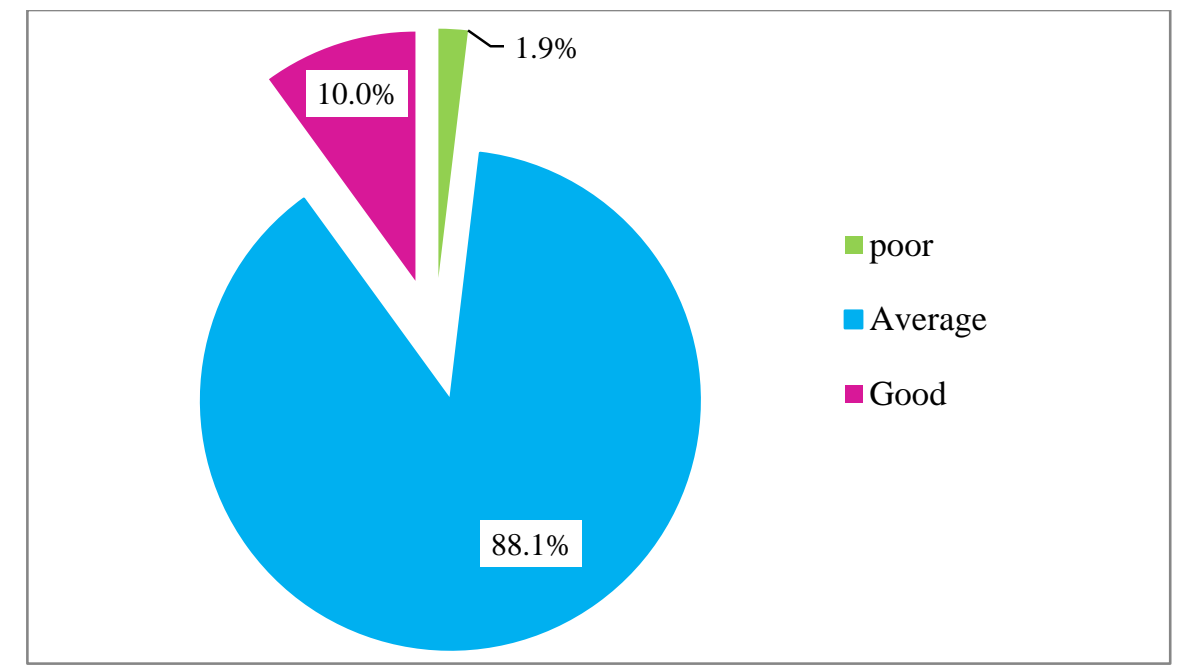

Figure 2. Distribution of the Nurses by state of psychosocial environment $(\mathrm{n}=\mathbf{2 1 0})$.

Figure 2 indicated that state of psychosocial environment had good 21(10.0\%), average 185(88.1\%), and poor $4(1.9 \%)$. 
Asian J. Med. Biol. Res. 2020, 6 (4)

Table 4. Distribution of the respondents according to workplace performance $(n=210)$.

\begin{tabular}{|c|c|c|c|c|c|c|}
\hline Performance & $\begin{array}{l}\text { Major } \\
\text { Improvement } \\
\text { Needed }\end{array}$ & $\begin{array}{l}\text { Some } \\
\text { Improvement } \\
\text { Needed } \\
\end{array}$ & $\begin{array}{l}\text { Meets } \\
\text { Expectations }\end{array}$ & $\begin{array}{l}\text { Often } \\
\text { Exceeds } \\
\text { Expectations } \\
\end{array}$ & $\begin{array}{l}\text { Consistently } \\
\text { Exceeds } \\
\text { Expectations } \\
\end{array}$ & Total \\
\hline Quality of Work & - & $78(37.1 \%)$ & $96(45.7 \%)$ & $31(14.8 \%)$ & $5(2.4 \%)$ & 210 \\
\hline Productivity & $7(3.3 \%)$ & $116(55.2 \%)$ & $61(29.0 \%)$ & $21(10.0 \%)$ & $5(2.4 \%)$ & 210 \\
\hline Knowledge of Job & - & $67(31.9 \%)$ & $104(49.5 \%)$ & $30(14.3 \%)$ & $9(4.3 \%)$ & 210 \\
\hline Adaptability & $9(4.3 \%)$ & $117(55.7 \%)$ & $60(28.6 \%)$ & $19(9.0 \%)$ & $5(2.4 \%)$ & 210 \\
\hline Dependability & $17(8.1 \%)$ & $120(57.1 \%)$ & $51(24.3 \%)$ & $15(7.1 \%)$ & $7(3.3 \%)$ & 210 \\
\hline $\begin{array}{l}\text { Initiative and } \\
\text { Resourcefulness }\end{array}$ & $71(33.8 \%)$ & $64(30.5 \%)$ & $54(25.7 \%)$ & $17(8.1 \%)$ & $4(1.9 \%)$ & 210 \\
\hline $\begin{array}{l}\text { Judgment and Policy } \\
\text { Compliance }\end{array}$ & $41(19.5 \%)$ & $89(42.4 \%)$ & $51(24.3 \%)$ & $25(11.9 \%)$ & $4(1.9 \%)$ & 210 \\
\hline $\begin{array}{l}\text { Relations with People } \\
\text { and Customer } \\
\text { Service }\end{array}$ & - & $90(42.9 \%)$ & $102(48.6 \%)$ & $13(6.2 \%)$ & $5(2.4 \%)$ & 210 \\
\hline $\begin{array}{l}\text { Attendance and } \\
\text { Punctuality }\end{array}$ & - & $68(32.4 \%)$ & $118(56.2 \%)$ & $20(9.5 \%)$ & $4(1.9 \%)$ & 210 \\
\hline Safety and Security & $9(4.3 \%)$ & $115(54.8 \%)$ & $63(30.0 \%)$ & $19(9.0 \%)$ & $4(1.9 \%)$ & 210 \\
\hline Leadership Ability & $68(32.4 \%)$ & $78(37.1 \%)$ & $42(20.0 \%)$ & $12(5.7 \%)$ & $10(4.8 \%)$ & 210 \\
\hline $\begin{array}{l}\text { Appraisal and } \\
\text { Development of } \\
\text { People }\end{array}$ & - & $137(65.2 \%)$ & $48(22.9 \%)$ & $19(9.0 \%)$ & $6(2.9 \%)$ & 210 \\
\hline $\begin{array}{l}\text { Planning and } \\
\text { Organization }\end{array}$ & $57(27.1 \%)$ & $75(35.7 \%)$ & $51(24.3 \%)$ & $17(8.1 \%)$ & $10(4.8 \%)$ & 210 \\
\hline Communication Skills & - & $106(50.5 \%)$ & $75(35.7 \%)$ & $21(10.0 \%)$ & $8(3.8 \%)$ & 210 \\
\hline
\end{tabular}

It was seen from the Table 4 that, out of 14 items, most of the Nursing ward in-charge mentioned that 9 items (productivity, adaptability, dependability, judgment and policy compliance, relations with people and customer service, leadership ability, appraisal and development of people, planning and organization and communication skills) of the respondents needed some improvement.

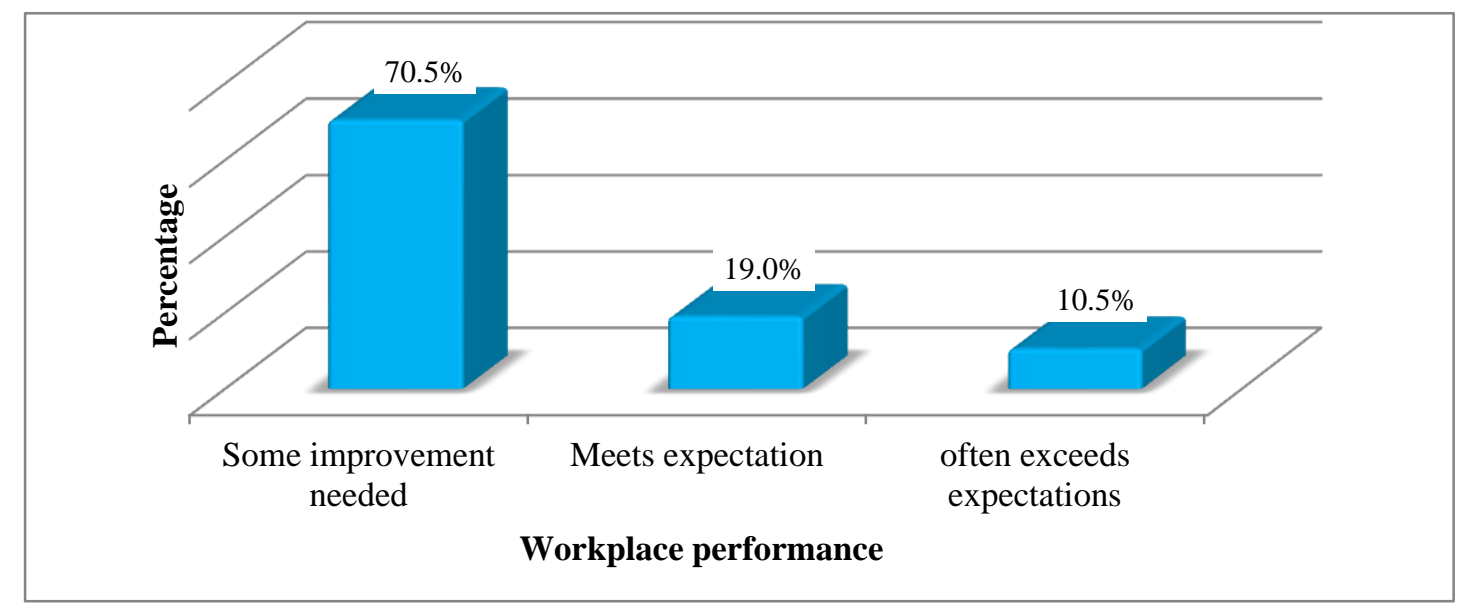

Figure 3. Distribution of the respondents according to level of workplace performance $(n=210)$.

Figure 3 mentioned that, out of 210 respondents, 148(70.5\%) respondents were needed some improvement, $40(19.0 \%)$ respondents were meets expectation and the rest of respondents were often exceeds expectations in their performance. 
Table 5. Distribution of the Nurses educational qualification in relation with their level of workplace performance and state of psychosocial environment in relation with their level of workplace performance $(\mathbf{n}=\mathbf{2 1 0})$.

\begin{tabular}{|c|c|c|c|c|}
\hline \multirow{2}{*}{$\begin{array}{l}\text { Educational } \\
\text { qualification }\end{array}$} & \multicolumn{2}{|c|}{ Workplace performance of the respondents } & \multirow[t]{2}{*}{ Total } & Test Statistics \\
\hline & $\begin{array}{l}\text { Some improvement } \\
\text { needed }\end{array}$ & $\begin{array}{l}\text { Meets and Often exceeds } \\
\text { expectations }\end{array}$ & & \multirow{5}{*}{$\begin{array}{l}\chi^{2}=44.942 \\
\mathrm{df}=2 \\
P \text {-value }=0.000\end{array}$} \\
\hline Post-graduate & $3(16.7 \%)$ & $15(83.3 \%)$ & $18(100 \%)$ & \\
\hline Graduate & $43(58.1 \%)$ & $31(41.9 \%)$ & $74(100 \%)$ & \\
\hline Diploma & $102(86.4 \%)$ & $16(13.6 \%)$ & $118(100 \%)$ & \\
\hline Total & $148(70.5 \%)$ & $62(29.5 \%)$ & $210(100 \%)$ & \\
\hline State of & \multicolumn{2}{|c|}{ Workplace performance of the respondents } & Total & Test Statistics \\
\hline $\begin{array}{l}\text { Psychosocial } \\
\text { environment }\end{array}$ & $\begin{array}{ll}\begin{array}{l}\text { Some } \\
\text { needed }\end{array} & \text { improvement } \\
\end{array}$ & $\begin{array}{l}\text { Meets and Often exceeds } \\
\text { expectations }\end{array}$ & & \multirow{4}{*}{$\begin{array}{l}\chi^{2}=5.859 \\
\text { df }=1 \\
P \text {-value }= \\
0.015\end{array}$} \\
\hline Average to Poor & $138(73.0 \%)$ & $51(27.0 \%)$ & $189(100 \%)$ & \\
\hline Good & $10(47.6 \%)$ & $11(52.4 \%)$ & $21(100 \%)$ & \\
\hline Total & $148(70.5 \%)$ & $62(29.5 \%)$ & $210(100 \%)$ & \\
\hline
\end{tabular}

The results revealed that there was a significant relationship between educational qualification and workplace performance of nurses $\left(p<0.001\right.$; pulled from $\chi^{2}$ text) and we also find out that there was a significant relationship between psychosocial environment and workplace performance of nurses $\left(p<0.015\right.$; pulled from $\chi^{2}$ text) (Table 5).

\section{Conclusions and Recommendations}

Workplace environment is helpful in increasing level of performance of the nurses. Psychosocial workplace environment like quantitative demands, work pace, quality of leadership, social support from supervisors, recognition/rewards, trust regarding management, respect, justice, stress and burnout clearly impacts on the mental health and wellbeing of nurses, which is most likely compromising performance and the quality of patient care. Furthermore, physical workplace environment is also considered as one of the important factors to affect performance. The results showed positive relationship between psychosocial workplace environment and nurses' performance and negative relationship between physical workplace environment and nurses' performance. This positive relation means that improvement in this factor can improve nurse's performance. Psychosocial workplace environment like supervisor support, good relation with co-workers, adequate work load, right justice, mutual trust, recognition and reward plans are helpful in developing a workplace environment that has positive impact on nurses' performance in the hospital.

\section{Conflict of interest}

None to declare.

\section{References}

Awan AG and MT Tahir, 2015. Impact of working environment on employee's productivity: A case study of banks and insurance companies in Pakistan. European J. Bus. Man., 7: 329-345.

Bhaga T, 2011. The impact of working conditions on the productivity of nursing staff in the midwife and obstetrical unit of Pretoria West Hospital, PhD dissertation, Department of Social Work and Criminology, Faculty of Humanities, University of Pretoria, South Africa. pp. 129.

Hossain MA, MAA Mustafi, MM Islam and MR Islam, 2016. Organizational environment and nurses' job satisfaction: a study on private hospital in Bangladesh. American J. Tra. Pol., 3: 79-86.

Källestål C, 2004. Health-promoting at workplaces - effects of health-promotion interventions in systematic literature reviews and in Swedish reports. State Public Health Institute, Sandviken.

Khoso AA, AS Kazi, MM Ahmedani, M Ahmed and I Ahmed, 2016. The impact of workplace environment that affect employee's performance in private hospitals of Hyderabad, Pakistan. Int. J. Multidis. Res. Dev., 3: 2833.

Latif A, 2014. Relationship between organizational climate and nurses' job satisfaction in Bangladesh. Master thesis, Department of Nursing science, Prince of Songkla University, Thailand. pp. 140.

Naharuddin NM and M Sadegi, 2013. Factors of workplace environment that affect employee's performance: a case study of Miyazu Malaysia. Int. J. Indep. Res. Stud., 2: 66-78. 
Pepple NM, EU Akpan and MJ Edem, 2017. Impact of workplace environment on health workers. Occu. Med. Heal. Aff., 5: 301.

Samson NG, M Waiganjo and J Koima, 2015. Effect of workplace environment on the performance of commercial banks employees in Nakuru town. Int. J. Man. Stud. Res., 3: 76-89.

WHO, 2013. The Health Workforce: Advances in responding to shortages and migration, and in preparing for emerging needs. Report by the Secretariat to the World Health Assembly. Executive Board, 132. Available: https://apps.who.int/iris/handle/10665/78640 